\title{
Local development in the rural regions of Eastern Europe: Post-socialist paradoxes of economic and social entrepreneurship*
}

\author{
Bruno Grancelli**
}

This paper aims to highlight some paradoxes of the agrarian transformation in Hungary and Poland and the ways they impinge on the working of private and cooperative farming. The first section reassesses the debate on the specificities of cooperative management in the light of the de-collectivization of agriculture. The second addresses continuities and changes in the symbiotic relationship between big coops and rural households within the two ongoing processes of Europeanization and economic globalization. The final section discusses the 'cooperative difference' and concludes with some analytical insights on who makes it both in coops and households.

Das Ziel dieses Beitrags ist es, gewisse Paradoxa der landwirtschaftlichen Transformationen in Ungarn und Polen sowie deren Auswirkungen auf die private und kooperative Landwirtschaft aufzuzeigen. Der erste Teil beleuchtet noch einmal die Debatte über die Ausprägungen von kooperativem Management unter dem Einfluss der De-Kollektivierung der Landwirtschaft. Der zweite Teil behandelt Kontinuitäten und Veränderungen in der symbiotischen Beziehung zwischen großen Kooperativen und ländlichen Haushalten innerhalb der laufenden Prozesse der Europäisierung und der wirtschaftlichen Globalisierung. Der letzte Teil bespricht die „cooperative difference" und schließt mit einigen analytischen Betrachtungen über die Zukunftsaussichten für Kooperative und Haushalte.

Key words: Cooperatives conversion, family farms, subsistence agriculture, rural development in CEE

* Manuscript received: 26.01.10, accepted: 08.08.10 (1 revision)

** Bruno Grancelli, Prof., School on Local Development and Global Dynamics, University of Trento, Italy. Main research areas: Industrial clusters, social capital and economic development, internationalization of SMEs. Corresponding address: bruno.grancelli@unitn.it 


\section{Introduction}

A good deal of research on private and cooperative farming is framed by the paradigm of rural (or 'post-rural') development which is often presented as an outcome of the theoretical exhaustion of the paradigm of agricultural modernization. However, the continuities and changes of the agrarian transformation in CEE and CIS countries seem to challenge this way of thinking. This exploratory paper aims to discuss some paradoxes of economic and social entrepreneurship that emerge in the modernization of post-socialist agriculture through a comparative look at cases studies in the rural areas of Hungary and Poland.

The first section of the paper provides examples of the paradoxes that impinge on the working of the former collective farms and that may be found at three levels. The first one lies in the fact that the industrialization of agriculture went along with a backward transition of sorts to a subsistence-type agriculture which largely recalls that of the 1940s. The second originates from the contradictions between the speed of the process of institution building and the slowness in the de-institutionalization of old structures. The third paradox becomes evident in the working of big cooperatives both in the local markets and the process of local/rural development.

Generally speaking, the 'cooperative difference' is thought to be made by the following factors: (a) coops contribution to bringing local monopolistic markets closer to competition; (b) their capacity to deal with externalities by keeping a presence in markets seen as unprofitable by investment oriented firms (IOFs) and, (c) their involvement in the formation of 'capital for social innovation' and community development through networking and learning processes (Novkovic 2007). The literature on the role of cooperatives in the post-socialist transformation highlights a set of contradictions in each of these functions. First, ex-socialist coops show some difficulties to act as competitive yardstick thanks to the significant amount of land of which they kept the property after the restitution laws (Hungary/Bulgaria). Given that households usually transferred their quotas to a cooperative, and the difficulties to set up a new private firm, the paradoxical result is that those coops are in monopsonic condition in the local market because they can pay low prices for the land they buy or lease (Meurs 2004).

On the other two functions coops are also lagging behind. There seem to be a lack of 'social cooperatives' or 'community-based enterprises,' that is, of organizations which try to combine the production of collective goods with an efficient management (Sikor 2002). There are little signs of an evolution towards associational forms based on a multi-stakeholder ownership whereby the distinction between production coop and consumption coop becomes blurred. More precisely, such multi-stakeholder ownership characterizes the big restructured coops which often operate within the food chains brought about by 
the 'supermarket revolution' of the last decade. There also seem to be few attempts to create reciprocity networks based on voluntary work, self-help and forms of cooperation within the process of sustainable rural development (Kelemen et al. 2007). The reasons of all that has something to do with the two other paradoxes of the agrarian transformation recalled above. On the one hand, the main trend is the reproduction of a subsistence-type agriculture and not the spread of small, efficient and labour-intensive firms; on the other, the programs of institution building need old (informal) institutions to get somewhat implemented through 'institutional corridors' defined by traditional local elites (Sehring 2008).

The second section of the paper put forward a rethinking of the debate on the cooperative difference in light of evidence on the agrarian transformation in Hungary, Poland and other CEE-CIS countries: a debate which revolves around some basic research issues. What kind of relation does exist between practice and theory of cooperation? May the contradictions of cooperative management be a source of innovation and organizational flexibility? Or, on the contrary, such contradictions will accelerate the conversion process from coops to investment-oriented firms?

The paper concludes with some insights for a comparative analysis of (a) forms of economic and social entrepreneurship that are developing at the intersection between market, community and the informal economy and, (b) the key actors that are straddling the divide between the speed of institution building and the evolutionary character of change in all those institutions that persist at the informal level and originate in the pre-socialist and socialist history.

\section{The 'cooperative difference': rethinking the debate in light of the post-socialist agrarian transformation}

The debate on the peculiarities of cooperative enterprises has revolved around two crucial issues: the efficiency of their management and their impact on the socioeconomic environment in which they are embedded (Sen 1966; Porter/Scully 1987; Furubotn/Pejovic 1970; Milgrom/Roberts 1992; Dow 2003; Gorton/Davidovna 2004; Merret/Walzer 2004; Mooney/Gray 2002; Novkovic 2007; Zeuli/Deller 2007). Among the classic problems in the cooperative management in the market economy one may find free riding in that individual members do not have to bear the whole cost of their collective decisions (Sen 1966). Another problem lies in the propensity to underinvestment stemming from the limited horizon of individuals who can gain from the productive use of a resource only for a limited amount of time (Furubotn/Pejovic 1970; Porter/Scully 1987). Still another problem lies in the divergent interests of 'principals' and 'agents' which generally stems from the separation of property and control and thus may also touch big cooperative firms (Milgrom/Roberts 1992). 
However, despite the governance problems quoted above, coops tend to reproduce themselves both in mature market economies and in catching up economies. If one looks specifically to CEE countries, one may notice that processes of demutualization go along with a certain persistence of production coops and the spread of purchasing and marketing associations, especially in the rural regions of Hungary, the former Czechoslovakia, Bulgaria and Romania (Borzaga/Spears 2004; Gatzweiler 2003; Gorton/Davidovna 2004; Meurs 2004; Thesfeld/Boevsky 2005; Bateman 2006).

The guiding principles of cooperation have been established by the International Cooperative Alliance (ICA): association on voluntary bases, democratic control on strategies and daily management, common property of all or part of the enterprise assets, autonomy from the public or private organizations with which the coops interact, training of the members and spread of information, cooperation among coops and, finally, participation in activities for the sustainable development of the local community approved by the membership (www.wisch.edu). The implementation of these principles is to be verified in three functional domains in which coops are involved. First, the capacity to act as competitive yardstick by rendering the market less monopolistic and more competitive. Second, the capacity to cope with externalities, that is, to mitigate market failures by keeping a presence in sectors seen as unprofitable by IOFs. Third, the capacity to generate 'capital for social innovation' through the creation of networks for the production of public and private goods that imply self-organized processes of social learning backed by adequate forms of institutional support (Merret/Walzer 2004).

The issue, though, is how to evaluate these three basic functions of the cooperative firm in the transitional societies and catching up economies of Eastern Europe. What should we check, and how, as far as the socioeconomic impact of cooperation is concerned? One stream of research has been reassessed by Gorton and Davidovna (2004) in their east-west comparison of the factors that impinge on the efficiency of private and cooperative farming. The two authors review a number of approaches focused on the balance between the efficiency gains brought about by specialization and the costs of monitoring the workers in coops and in IOFs. Yet, Gorton and Davidovna point to the fact that in CEE countries cooperative members are very often 'residual claimant' in that they contribute not just with their work, but with parcels of land they acquired with the laws on restitution. Their conclusion then is that one cannot single out an optimal firm from the point of view of efficiency that is bound to prevail once the reform of the agricultural sector is being completed. It is indeed difficult to generalize on the relative efficiency of coop and IOFs because of the complex interplay between structural factors (soil, climate, etc.) and subjective factors such as individual and household strategies. Besides, the merger of firms may have an impact in terms of technical and allocative efficiency, but small 
family farms may also be efficient if an adequate set of services is also available to them (Gorton/Davidovna 2004:11).

The lesson here is that economic and social entrepreneurship emerging in rural regions of CEE are to be analyzed in two stages of the transformation process: (a) the Nineties, with the laws on restitution, privatization and restructuring of state and cooperative farms and, (b) the last decade with the Acquis communautaire, the national policies of 'rural regeneration,' the 'supermarket revolution,' the modernization of commercial agriculture, the persistence of subsistence farming, and the slow growth of second generation cooperatives.

\section{Transformation of collective farming: continuities ad changes in the symbiotic relationships between coops and rural households}

At the outset of systemic transformation in CEECs, a general consensus existed on the necessity to modernize the agricultural sector. Yet in Western Europe, where agriculture has been modernized, the modernization paradigm has been widely criticized (van der Ploeg et al. 2000; Sotte 2003; Gatzweiler 2003; Cavazzani 2006; Csurg et al. 2008; Juska et al. 2005; Fonte 2008). Such criticism may be summarized in two points. First, the industrialization of agriculture led to an unsustainable production model due to the high dependence of the sector from exogenous factors that 'squeezed' it and brought about a constant reduction of the ratio between earnings and production costs. Second, firms restructuring resulted in a decoupling of agricultural production from the local environment and in standardization processes linked - among other things - to the "regulatory treadmill" at national and EU level (Cavazzani 2006).

\subsection{National legacies of socialist agriculture: similarities and differences}

The criticism of the modernization paradigm is not unfounded. Yet indicators such as, for instance, the one million horses on active duty in Polish agriculture (Chloupova 2004) should warn us against the risk of proposing ideas ahead of times. The comparative study of agrarian transformation in CEECs cannot neglect the legacies of collectivization and the socialist industrialization of rural areas. Hence, some basic outcomes of the socialist agrarian policies and their impact in different national contexts must be recalled here. First, these countries were under-urbanized as all the others in Eastern Europe for socialist industrialization had been extensive and shared many features with those of latecomer countries. Second, planning priorities brought about a stratification of sectors, enterprises and places so that infrastructures and services were at the lowest levels for a rural population made of workers-peasants. Third, big collective enterprises - mainly state farms in Poland and cooperatives in Hungary, Bulgaria or Czechoslovakiab - began to dominate the economic landscape in rural areas from the Seventies on (Swain 2000). 
Some cross-national differences are also to be highlighted for Hungary (along with Bulgaria) and Poland may be roughly taken as the best and the worst environment for the development of cooperative enterprises. In Poland small family farms did not disappear under socialism. Rather what would change were their links to big state firms at the outset and to more market oriented enterprises later on. In Hungary, on the contrary, the starting point of socialist agriculture was the "Neo-Stalinist Model" of the Fifties which meant a rise in the state prices, a reduction of mandatory consigns a narrowing of the salary gap with industry, an improvement in welfare provisions, and encouragement to differentiation of activities. In the successive decade, all this was followed by the New Economic Mechanism which would bring about a couple of welcomed changes. First, rural households were allowed to use the socialist distribution channels and, second, coops began to enjoy more economic freedom within a 'quasi-market' environment whereby individual members used to work both for their coop and their household (Swain 2000).

A case whereby the legacies of collectivization are quite different from the Hungarian and Polish ones is Russia due to culture, and political, social and economic institutions. In Russia it turned out to be particularly difficult to break the old industrial empires. This applied to the big kolkhozes as well for reasons that were only partly related to the scale and type of production. Indeed, collective farms were a component of: (a) an unreformed command economy in which agriculture was - much more than in other socialist countries- subsidized and dependent on industrial inputs; (b) a vertically integrated food processing industry and, (c) a state welfare system whose insufficiencies used to be partially compensated by the concession of family plots to the rural workers of the 'industrialized villages' (Harrod-Menzies 2006; Oswald 2007)

\subsection{Two domains of change in the Nineties and the mother of all paradoxes}

The first domain of change lies in the symbiotic relationships between coop and IOFs, on the one hand, and the new small farms that began to spread as an outcome of the closing up or restructuring of collective farms. The second one refers to the behavioural patterns of actors who play a key role in the agrarian transformation and the implementation of policies for 'rural regeneration'.

In every country of Eastern Europe, the socialist economic elitehas been able to reproduce its social position mainly through its control on the implementation of the privatization processes. What happened everywhere was that those officials who had control over the means of production under socialism were also those who acquired property rights in state owned enterprises by asset stripping and the spinning off of subsidiaries (Windolf 1998:343). This indeed was the main outcome both where privatization has been a top-down or a bottom-up process. The difference, however, lies in the ensuing possibilities for enterprise restructuring according to the market principles. This point may be 
illustrated by contrasting the transformation of the institutional environment in Hungary and in Russia.

The process that has been unfolding in Hungary was that of an integrated ownership pattern in that it frequently integrated different kinds of owners within the firm with foreign investors often playing a prominent role. This pattern of 'recombinant property' (Stark 1996:1019) was a risk-spreading device of sort. Yet, risk-sharing implies a social and institutional context in which risk-taking is accepted and the production system is open to the global economy. The framework of privatization processes in Russia lies in stark contrast with the Hungarian one.

A basic aspect of the Russian difference is apparent in the way reforms were implemented. The problem here does not lie in a top-down approach which was indeed common to the countries of Eastern Europe. Rather, it lies in what had been happening in the social organization of the former Soviet state. In Poland, for instance, one may speak of a state "partially appropriated" by informal networks and groups. In Russia, however, what took shape was 'clan state' in which cliques of officials have been able to privatize sectors of the state for which they are responsible (Verdery 1998). The top-down implementation of reforms did not prompt economic actors to shift from a reliance on networks to a reliance on law. As Stephan Hedlund (2001:216) puts it, the institutional changes of the early 1990s "would have required successful introduction of a system of secure property rights into a social system where the very notion of 'rights' as such was seriously underdeveloped."

In Russia, a process had been unfolding which led to both the privatization of the state and the dominance of that state over big business. According to Andrey Yakovlev ( 2006:1048) the bulk of the Russian big business that chose the strategy of a close integration with the state gets subordinated to an administrative model of economic regulation in which "the game around the rules" is being played now as it was in the previous stages of reform. A game which was also played in the Soviet era when it was almost impossible not to break some of the many directives and regulations and being penalized if the higher authorities could not be convinced to close one or both eyes (Grancelli 1988).

What is worth adding here is that the way big business is forced into a condition of state-dependency is cascading down to the level of the relations between former big kolkhozes and rural households. The latter indeed survive on their small plots of land thanks to the resources they get, in a way or another, from the former kolkhoz (see boxes 5 and 6).

These new farming organizations are managed by ex-directors of state and cooperative farms but also by people with previous experience in the 'second economy' of socialism. Thus, the actors one may find in different combination 
in the rural regions of CEE and CIS are now the following: (a) small farmers of the subsistence agriculture whose subsistence is also due to some extra incomes (pensions, subsidies, etc.) that form the bulk of the rural population, especially in the lagging regions and the 'Eastern peripheries'; (b) small and medium family farms that try to live on agriculture whose owner come from state and cooperative enterprises; (c) big firms in the agrifood chain managed by former socialist directors and, (d) big and middle restructured coops heading towards privatization (Swain 2000; Bateman 2006). The first and second types of actors include a variety of autonomous work as an alternative to unemployment. In fact, many of the 'rural entrepreneurs' are former industrial workers who become self-employed out of necessity and do not think of investments or core business insofar as they see their activity as a substitute source of income. Also worth mentioning is the fact that a significant increase of new job opportunities is only apparent in regions bordering with western Europe, and that very few of the new entrepreneurial opportunities stems from national and EU support policies. The problem though lies not just in the unintended effects of policy implementation: it also has something to do with an anti-business attitude quite common within a rural population still overwhelmingly made of workerspeasants (Buzalka 2008).

On the policies for rural development, the emerging trend seems to be that local authorities are usually powerless for lack of funds, administrative inexperience in front of a growing responsibility for local development policies on which the pressure of economic interests has began to growth. A slow change in the composition of the local elites is nonetheless taking place in Poland, Hungary, and also in Bulgaria, even if the "post-socialist growth machine" is often managed by people who used to manage that of late socialism (Kulcsar/Domokos 2005; Oswald 2007).

To sum up, the comparative investigations of these fields of change shows evidence of a macro-level paradox emerging in the early stages of the agrarian transformation, namely that reform policies brought about not only a modernization of commercial agriculture. As a matter of fact, these policies and the opening up to the global economy also favoured the extensive growth of a subsistence agriculture with some resemblance to that of the $1940 \mathrm{~s}$, that is, modernization went along with a process of re-traditionalization in the rural economy and society (Brown/Kulcsar 1999; Gutkowska 2003; Small 2003; Fadaeva et al. 2004).

The post-socialist machine is bringing about much less growth in the Russian countryside (especially in the northern regions) whereby the reform of local government seems to have yielded too little and too late. In this case, the agrarian structure keeps being based both on mass production and family plots despite the legal changes in the ownership of farms. In Russia an 'institutional deficit' is still apparent in the lack of organizations that could help SMEs and 
farms to solve their problems. Actually, in front of powerless local governments, Russian farmers usually were not able to organize themselves also due to the absence or weakness of support from the government and NGOs. Consequently, the symbiotic relationship between the ex-kolkhozes and rural households is still strong, even if there appears to be an increasing divergence in the pathways of change in different localities (Kalantaridis et al. 2007). What emerges from the case studies in Russia has been aptly summarized by Leo Granberg (2007:59) in these terms: "... private plot holders are not in a great hurry to change their modus operandi and become fermery. They will, however, engage in more non agricultural activities either as registered companies or in the grey economy."

However, the opening up of the agrifood sector to FDI and the process of accession to the EU will foster further changes in the relationship between big cooperatives and small family farms.

\section{The cooperative difference in CEE management: If it is there, who is going to make it?}

Research on the first stage of the agrarian transformation has been mainly focused on the supply side of change, that is, on economic reforms, restructuring of enterprises or the reconstruction of the financial systems. It is only recently that the process has been tackled from the demand side, that is, from the changes in the distribution sector. In other words, a new stream of research began to emerge on the 'supermarket revolution' currently unfolding in CEE countries within the processes of Europeanization and economic globalisation The evidence provided by this literature is still scattered, but it yields useful accounts on the relations between big distribution chains and local producers, on joint ventures in the agrifood sector, and on the ongoing processes of 'Regoverning markets' in the region (Reardon/Swinnen 2004; Dries et al. 2004; Milczarek-Andrewska 2008). The changes of the last decade had an economic impact, but their socio-cultural consequences are also noticeable both on consumers and the actors of interest here, that is, agricultural producers. The impact of the supermarket revolution is thus taken here as the background for an assessment of the cooperative difference in addressing market failures and in building capital for social innovation.

\subsection{Cooperatives, small farms and market competition}

The supermarket revolution was set in motion in CEECs by the same determinants which triggered the process elsewhere in the world such as: rising per capita incomes, urbanisation, liberalisation of investments in the distribution system, and technical and organizational changes in the procurement systems of supermarkets. The sector especially affected by these changes is the dairy sector whose capacity to attract foreign investments was second only to that of the automotive industry. The impact of EU accession has been significant as well 
insofar as supermarket chains have been providing assistance to farmers to comply with EU norms, especially on the quality of products (Reardon/Swinnen 2004).

Multinational companies have played an increasingly important role in the modernization of Polish and Hungarian agriculture. Yet their impact has been differentiated due to the relative weight of structural and cultural legacies of the previous regime, the capacity of implementing reforms, the degree of integration of national economies in the globalisation processes, the costs of labour and the structure of the agrifood sector. First, household farms usually do not have enough investment capacity to insert themselves into the new value chains. Second, they find it difficult to reach the scale of production and the quality standards to compete in the market. Third, agrifood industries prefer not to deal with a myriad of small producers because of the negative implications in terms of transaction costs. Finally, it is worth noting that employment in commercial agriculture has been decreasing dramatically due to the restructuring of enterprises (Dries et al. 2004).

However, a set of shock absorbers are more or less effectively working in the three domains referred to above. In the economic sphere forms of assistance to small farmers are put in place in matters such as investments in human capital, management techniques, quality inputs and machinery. Moreover, a good deal of former coops and state farms are now included in the agrifood chains so that they may act as buffers between the changes in the distribution channels and the small family farms. Also important is the fact that the modernization of the dairy sector has potential implications in terms of local/rural development (LRD) for it favours the spread of off-farm activities such as packaging, quality control and services to enterprises and others. As for small producers who cannot specialize and rely on traditional distribution channels, they do not remain passive but look for alternative sources of income. It is not by chance that some experts also suggest support policies for these farmers such as, for instance, the conservation of environment (Milczarek-Andrewska 2008).

The conclusion Reardon and Swinnen draw from their investigations is that there are clear signs of distributive sector assistance to small producers which help compensating, up to a certain extent, their market failures. This positive outcome might be even greater if there were a higher degree of development of associational forms among agricultural producers. Some evidence on this may be found, especially in Hungary whereby a new generation of agricultural associations is gaining ground as a brief sketch of two successful purchasing and service coops may demonstrate.

In Poland, on the contrary, cooperation among small producers seems to remain quite rare because of an entrenched mindset and a lack of reciprocal trust outside the interfamily network (Brown/Kulcsar 1999; Small 2003). Be it as it may, there seem to be a slow spread of purchase and marketing cooperatives 
that may increase the bargaining power of small producers in front of big distribution (Wilkin et al. 2006). Four typical cases in Hungary and Poland are sketched below (see Boxes 1, 2, 3 and 4). These cases may also be taken as empirical references for the discourse on the third function which make up the cooperative difference: the creation of capital for social innovation (Box 4).

\section{Box 1. Three cases of new cooperatives in Hungary}

The first coop (Kapostai) was founded in 1994 by 35 small owners as a non profit organization for the purchase of seeds and fertilizers. Success is noteworthy so that initial membership grows up to 2000 people in the next five years. In 1995 a similar society is founded for the collective selling of fruit and vegetables, which gets closer to 300 members in 2002. The coop organizes the buying of material inputs and a number of selling outlets. In order to improve competitiveness and better product quality, the coop may also work on the basis of production contracts with individual producers and makes efforts to purchase inputs of the same type. The annual surplus is redistributed among members proportionally to their turnover with the coop, after a deduction for deposits and costs.

The second case is a coop which already existed in the pre-socialist period and started anew in 1993 as Haidú Gazdák Agricultural Association and three years later as Farmers' Club, and finally, in 1999, as Purchasing and marketing coop of Gazdák (PMCHG). The new association focused on: gathering and spreading technical and commercial information, joint purchase of inputs and marketing of products. Also important was the function of accessing additional government support. The first coop retained its original form until 2000 despite the possibility, according to the law of 1992, of becoming a joint stock company. This choice seems to be related to the initial composition of membership: almost two thirds is made of retired people. Yet membership changes increasingly over the period up to 1999 when the number of external actors overcomes that of initial members and the coop turns into a joint stock company. The stated reasons of the changeover were to secure more sound foundations to property rights, more efficient management of production, easier access to investment capitals, better image of the firm and to increase the returns of shareholders.

Sources: Szabo/Kiss 2004; Forgacs 2008 


\section{Box 2. A limited liability company for the buying and selling of fruit in Grojec}

The town of Grojec (50 km from Warsaw) is part of the main area of fruit production in Poland. The SUN-SAD is a company for the commercialization of apples founded by ten partners linked together by a long, common experience.

The partnership was founded in 1997 and the activity begins under the slogan "Ten vitamins from a sunny Polish orchard"

A year later the partnership turns into a limited liability company and a program of investments is devised by the owners-shareholders. Production and storage are modernized through credit on easy terms. Forty types of apples are sold to supermarket chains, wholesalers and retailers. A significant quota goes to export. The management and marketing policies are decided collectively during the weekly meetings. The members may also sell individually, but it is agreed that selling through the society has the priority.

The co-owners are also involved in the associations of interest representation at local and regional level. They also cooperate with the foundation for the development of rural cooperatives. In relation to this, the intention is to seek the collaboration of the British Know How Fund, as happened initially with a Dutch consultancy firm. The strategy is to expand the business and to produce according to EU standards.

Source: Metera 2001

\section{Box 3: A group of producers in organic farming in Brodnica}

Groups of organic farmers began to spread in the area back in the early 1990s also thanks to training initiatives by German and Swiss specialists. The first representative organization of these farmers in Poland was founded in 1989 under the label of Ekoland which, in a short amount of time, promotes the establishment of 58 farms.

As in the previous case, the Association takes shape from a set of personal and institutional links among members who participated in courses, instruction trips and various kinds of common activities. In this case, however, the common activity of members is limited to professional training, and the promotion of organic farming in fairs and the media. Shortly afterwards, the new law on the associations of buying and selling allows a number of more market-oriented members to set up an informal group (Brodnica) that involves 20 small producers of wheat and fruit. In 1993, a group of three people set up a cooperative for the organic farming of fruit and vegetables which, a few years later, turns into a limited liability company supported by both the regional project managed by Ekoland, and the Heinrich Boll Foundation. With 
the aim of extending the production mix, the coop members arrange an agreement with a bakery in Torun. In the meantime, new sources of funding are sought after at the national level and abroad to enlarge and modernize the warehouse.

Production is checked by the Ministry of Agriculture and also by a Dutch agency, and it is sold to wholesalers, supermarkets and retailers all over the country. Due to the scarcity of financial resources, the farmers devise forms of mutual support in the commercialization of production, and regulate their terms of trade also in terms of barter. The main problems at the beginning stem from the unsatisfactory level of prices and the incapacity to secure a continuous flow of deliveries, especially for vegetables, due to the unresolved logistic problems. In their marketing activities, the members are assisted by three part-time employees and an expert in organic farming. Despite its problems, the organic farm and the plant for the production of whole-wheat pasta have been able to hire 12-14 full time employees and 40 seasonal workers The big prospective problem remains undercapitalisation.

Source: Metera 2001

\section{Box 4. Social capital and leadership in two Hungarian coops in the commercial agriculture}

Trust and reciprocity. Both components of social capital seen as important for the development of the cooperative model. Yet, members of the traditional coop (Beke) mainly trusted national and EU institutions while in the second generation coop (PMCHG) members trusted their partners first and foremost.

Communication and information. Beke members are more inclined to seek information from the organizational leadership and national media. PMCHG members more inclined to gathering information from community leaders. In both cases, a good flow of information is pointed out, even though the flow shrinks on investments issues. A shared view: information management is a prerogative of organizational leadership and communication with external actors is the best way to improve the chances of getting institutional support.

Community, social networks and informal institutions. The motivation to help' the community remains strong in both coops, even if help is conceived of in terms of time, not money. Shared view on the mediation of internal conflicts: involvement of the leadership and/or discussion of controversial issues at the general meeting. The presence of internal cliques was mentioned only by two of the ten people who gave in-depth interviews. Institutional environment and the cooperative model. The attitude of members towards the mutuality principle began to change with the introduction of radical reforms. On this, the shared view was that the law o restitution of 1992 was ill conceived and badly implemented. The level of trust among coop members dropped steadily since 
then, and people became more reserved and less inclined to engage in cooperative activity. Almost all the 10 interviewees stated the lessening of their trust in the government in charge, especially in the traditional coop. A disappointment was also apparent concerning the policies adopted in the process of accession to the EU.

Source: Forgacs 2008

However, successful big coops within the transformation of a commercial agriculture wide open to FDI and subject to EU Common Agricultural Policies are just one side of the agrarian transformation in Eastern Europe. The other is the side which includes the bulk of rural population, namely the subsistence agriculture and rural households still largely dependent for their livelihood from former collective farms turned into IOFs or new coops. It is comparative research on continuities and changes in that symbiotic relationship the may help rethinking the debate on the cooperative difference in the catching-up economies of CEE and CIS (Box 5 and 6).

\subsection{Kolkhoz legacies, rural livelihood and the agony of a symbiotic relationship}

The focus of the comparative research must also be directed to another context of the relationship, that is, to the actors of a less advanced agrarian transformation in local communities largely out of the reach of exogenous factors of change.

It is in the lagging rural regions and the 'Eastern peripheries' that negative socio-demographic changes are dramatically evident in terms of ageing of the population, mortality, emigration, growing poverty (Brown/Kulcsar 1999; Small 2003). These are indeed the places whereby the social costs of economic transformation are especially acute in terms of unemployment and reduction of welfare provisions (Shubin 2007). It is there that rural livelihood is largely based on a set of non market economic activities of households in a grey area between legality and illegality (Kalantaridis et al. 2007). Granted, the activities in the informal economy are not a new phenomenon: they emerge both from the traditional peasant society and the real working of Soviet enterprises, especially in low priority sectors (Grancelli 1988). They are embedded in the rural society of today, even if for different reasons than in the past: they have to do with the survival strategies of household usually within the agony of a relationship established in another era (Neef 2004; Wallace/Haerpfer 2004; Heinonen et al. 2007).

\section{Box 5 A former collective farm and a stanitsa in Kuban}

The former kolkhoz turned in 1992 into a limited shareholding company. This big breeding factory was one of the best in the region of Krasnodar. It still keeps a good level of economic viability, mainly due, however, to the low cost 
of labour. On the other hand, the salary level is not the main incentive for people working in this organization. Today (as in the past), the real incentive for rural households is to access the resources of the farming enterprise and use them as inputs for their individual farm. Besides food products, shareholders receive a small dividend from the piece of land they rented to the new enterprise. The point though, is that they get only about $15 \%$ of the claimed land profitability so that, if they would decide to sell their share, they would do this at the rate of exchange established by the former kolkhoz.

By the late Nineties the management became the real master of the enterprise and began to impose new production standards under which workers get a certain salary, plus some resources for household farming with the aim of bringing the old tactics of stealing to an end. However, the problem is that salaries remain low and the legally allotted fodder is both scarce and distributed according to the degree of 'closeness' to the bosses. The only alternative way to access to the common pie is to participate in the 'voluntary-compulsory work' in weeding and harvesting vegetables.

The reduction in the possibilities of informal acquisition of resources from the ex-kolkhoz may be partially compensated by the development of exchanges based on kindred relations and business ties which, as a rule, involve someone working on the big farm. An interesting outcome is that such exchanges usually lead to the formation of family cooperatives of a sort that put in common a set of resources and opportunities (money, materials, time) of several families.

Source: Fadaeva et al. 2002

The question emerging here relates to two possible evolutionary paths. A first possibility is that survival household strategies turn out to be part of a retraditionalization of rural communities that may threaten the reconstruction of civil society. A second possibility is, instead, that they may have a potential in terms of local development and societal modernization. In any case, the first step to tackle this issue is to gather preliminary evidence what kind of outcomes are brought about by the strategies of households within the agony of the symbiotic relationship with the former Soviet-type cooperative.

\section{Box 6. Production coops and rural households in Saratov}

In the village of Povolgie the main employer has always been the kolkhoz. In 1991 the management tries to implement a strategy of radical restructuring which meets with the strong opposition of the majority of the labour force. The management and a group of the most qualified workers then leave and take with them the best machinery and their property shares and form a new production association which is able to keep a good level of economic viability. In successive years, a process of apportionment of small farms from the ex-kolkhoz 
keeps going, even if only about two thirds of the new small firms are really working.

To the extent that the influence of the ex-kolkhoz decreases, elements of rural self-organization began to emerge in the management of the commons. For instance, when the kolkhoz practically ceased to keep up the water supply system, at a meeting of the village inhabitants, it was decided to raise funds to be earmarked for that purpose. On this, the most successful farmers exerted a leadership role.

Even in this case, a new stage of adaptation of households began to appear as a consequence of the breakage of the "symbiotic mechanism of family-farm coexistence." Families tried first to siphon off from the kolkhoz as many resources as they could. At the same time, they also began to try to restructure the homestead according to criteria of profitability. Yet the problem was the lack of financial resources. For instance, a steady salary was earned only by a small minority of women who worked in the public sector, and for half of the 17 families of the sample, monetary income was only half of overall family revenue. Hence, there exists some nostalgia for the good old days of the Eighties when life was secure, and the house replete in the kolkhoz and its little company town.

Nonetheless, the household interest for private agriculture is growing. It is, however, a very traditional agriculture where, in recent years, "a slow but unmistakable return to the times of individual peasant farmsteads of the beginning of the last century was taking place."

Source: Fadaeva et al. (2002)

\section{Lessons learned and generalizations}

Four generalizations may be cautiously drawn from the case studies on coops in the modernization of commercial agriculture in CEE countries First, most members of production coops which remained as such seem to long for the good old days of the quasi-market conditions of a partially reformed socialist economy: they state their support for the mutuality principle and recall the high levels of social capital that existed in the past. However, in a growing number of cases, the majority of coop members decide that the conversion into an IOF may be the best way to secure their rights as residual claimants to economic returns.

Second, the members of the not many marketing and service coops explain their choice to associate with their difficulties, as individual farmers, due to the rising production and transaction costs of their relationships with supplier and customers. Third, the cases clearly show the presence of path-breakers both in big coops and small household farms. Indeed, organizational leadership seems to play a crucial role either in keeping production coops alive or convincing people to join new types of associations or to turn a coop into a joint stock (or limited liability) company. Fourth, a reservoir of economic and social 
entrepreneurship is also noticeable in the subsistence agriculture, and it may take an organizational shape with the help of pull factors such as, for instance, commercial opportunities and availability of new resources. In those cases, households' strategies may go beyond the horizon of a networked poverty to build forms of interfamily cooperation that may be conceived of as precursor of the cooperative or private enterprise.

How to explain this explanandum?

The construction of the cooperative difference in CEE management as research object teaches three methodological lessons. The first one is that:

To understand the cooperative difference one need to retrieve variables that are often missing in economic approaches, namely those related to the production of capital for social innovation. Yet, retrieving extra-economic variables should not led us to neglect a clear evidence, namely that path breakers, both in private and cooperative farming, are striving for a consolidation of their property rights

In other words, what should be done is the operationalization of human and social capital for these concepts becomes crucial if the efficiency of farming is framed within the general issue of local-rural development.

However, to elaborate further on this issue, a second lesson is to be learned:

The production of capital for social innovation is to be located in time and space, and framed within the changing relationships between former collective farms and rural household in a set of local contexts differentiated by: type of agriculture, weight of path dependency, implementation of reform policies, and patterns of socioeconomic change.

The differentiation of local contexts is also due to exogenous factors related to the degree of openness to the global economy and the impact of programs for the modernization of agriculture and rural development. Thus, the third lesson is that:

The weight of path dependency and the ways innovators break the path also depends on external pull factors whose combination is different in CEE and CIS.

A comparative analytical framework should then theorize the cooperative difference within the processes of rural development in CEE countries without separating the economic dimension from those of institution building and deinstitutionalization of existing structures. The case studies reviewed here also provide theoretical insights for this endeavour.

A remarkable step ahead in this direction is the cross-national comparison carried out by Mieke Meurs (2004) within the framework of transaction cost economics. Drawing from evidence in Hungary and Bulgaria, Meurs tackles two interrelated questions: Why the development of private farming has been so slow? Why such a persistence of production coops and the transformation of many former kolkhozy into holding coops that integrate many small family 
farms? The reason is that the economic returns of private farming remain low in comparison to those of big coops which operate in imperfect markets and are managed in ways that have little correspondence to the classic principles of cooperative governance. In such conditions, transaction costs to be considered are not just those of monitoring labour: such costs are high for private farming mainly due to the imperfections of input and output markets. On the contrary, production and transaction costs of big coops may be kept relatively low because of the reserve of production factors and social capital inherited from the previous regime.

The explanation Meurs provides is framed by a transaction cost approach in which extra-economic variables are also included to explain the cultural barriers initiators face while trying to create a new business. Yet, these variables play a residual role for the research question is whether or not the persistence of former collective farms is, on the whole, hampering the efficiency of farming in the catching up economies of CEE.

That comparison is focused upon the first aspect of the cooperative difference. For example, a paradox Meurs notes in the explanandum is that the big amount of land inherited by former-socialist coops in Hungary and, even more, in Bulgaria has put them in a monopolistic condition in the local market. Nonetheless, this concentration of ownership has also favoured a reduction in transaction costs of buying and renting land. The point then is: Big cooperatives may have not performed well as competitive yardsticks, but they had somewhat favoured the consolidation of private property rights on land after the fragmentation of property brought about by the laws on restitution. Changes may occur though, both in the management of big coops as in small family farms even in a condition of imperfect markets. Thus, the consolidation of property rights may act as a pull factor for the expansion of private farming if a small group of farmers succeeds in expanding its control on the arable land (Meurs 2004).

This example is theoretically relevant insofar as it allows thinking about the applicability of the property rights approach to this research object: an approach seldom applied even to cooperatives in developed market economies. In general, property rights have been used to address the problems of resource allocation in the firm: Who are the decision makers? Who are the residual claimants on economic returns? Merret and Walzer (2004), in their study on coops and local development, start from the classic question of what determines the choice of an organizational form by the enterprise. According to them, this perspective may also be applied to coops to understand the way they align the incentives of their members and stakeholders and the possible consequences of this in terms of demutualization. In other words, when the membership becomes too heterogeneous, the principal-agent problems applies to big coops as well unless 
a strong governance and an effective representation of interests are in place (Merret/Walzer 2004:58).

The holding coops, successors of collective farms, are also cases in point for they have a highly heterogeneous membership which includes external shareholder-investors. Can we apply to them the same approach? The idea put forward here is that we can insofar as the property right approach has acquired a more processual character than it originally had, and this allow further thoughts on the principal-agent model in contexts in which many agents are also residual claimants. On the comparative analysis of these changing contexts, some concluding remarks.

There is today enough evidence that the rebuilding of market institutions in post-socialist countries cannot be seen as a process of unfreezing of an institutional arrangement to refreeze it in a new configuration (Boudreaux/Aligica 2007). A processual approach is needed which goes beyond the insertion of cultural factors into the transaction costs approach to the evolution of post-socialist agrarian institutions. In other words, a comparative approach should also account for the different transition paths that are going to change same basic structural elements of the previous economic regime. The point on this has been clearly made by Ingrid Oswald (2007:225) who proposes the concept of 'industrialized village' for explaining the social and cultural outcomes of the Soviet-type industrialization of the countryside. In Russia, much more than in Hungary and Poland, the consequences of that process are: (a) a lack of economic basis for the running of private and competitive firms; (b) the absence of social actors willing to transfer administrative functions from the former kolkhozes to municipalities and, (c) the overwhelming presence of people accustomed to having a waged job, that is, a rural population without farming skills.

Many analytical insights may be drawn from a processual approach in which both structural and cultural legacies are given due consideration. For instance, Jane Harding (2004), in her case study on the local governance in Wroclaw, takes the concept of path dependency into account for it is important to understanding the existing legacies. Yet, she does not conclude that new institutions should be allowed to emerge in a path-dependent and incremental way. Rather she emphasizes the role of local path-shapers and the way they are forging new structures in a context in which the capacity of governance is shaped by fractured interests, power relations, and the intervention of external player.

Two lessons emerge from these studies. First, informal institutions such as, for instance, those which give some groups a disproportionate access to the decision making process are positing a quite different scenario from that of freely contracting individuals. Second, the role of exogenous players may have a highly variable importance in the development and governance of localities. 
Thus, a basic feature of a processual approach to the changes in property relations is its focus on strategic behaviour of path shapers in different social and institutional contexts. Examples may be the nomenklatura who have converted their social capital into economic capital; the workers that may have turned their collective 'blockade capital' into individual social capital or the importers of intellectual capital from western market economies (Hardy:313316). Examples may also be the villagers of the lagging rural regions that rely on mutual help that sometimes may lead to the creation of 'family cooperatives' (Fadaeva et al. 2002; Shubin 2007; Oswald 2007).

The problem in general, especially in CIS, is the lack of an adequate governance structure to implement the new legal norms which also is a problem of deinstitutionalization of old structures. Thus the challenge here is how to explain the behaviour of path-shapers in this process, only partially intentional, of institutional change in which local administration is the meeting place of formal and informal structures. If this 'messy middle' is brought into the picture we may see the usefulness of the concept 'institutional bricolage' to understanding how local development brokers recombine traditional and Soviet ways of resource distribution with "post-Soviet [pseudo-]participatory processes as rules demanded by donors institutions" (Sehring 2008:19).

This implies that in the local polity-economy we may have different combinations of forms of self-help along with the political decision making. Hence the theoretical challenge for the application of property right approach to the cooperative difference in CEE management is that of a conjoint analysis of two processes. First, the interrelations between economic development and the consolidation of property rights of innovators and path-shapers. Second, the way government and donors' institutions favour the growth of public entrepreneurship for the creation of new a polycentric governance of local development.

\section{References}

Bateman, M. (2006): Rediscovering the value of the co-operative sector in SEE: History, current developments and some ideas for the future, in: Dallago, B. (ed.): Transformation and European integration. The local dimension. New York: Palgrave.

Berend, I.T. (2007): Social shock in transforming Central and Eastern Europe, in: Communist and Post-Communist Studies, 40, 269-280.

Brown, D./Kulcsar, L. (1999): Rural families and rural development in central and eastern Europe, paper presented at the Research Conference on Rural Development in Central and Eastern Europe, Podbanske, Slovakia.

Buzalka, J. (2008): Europeanisation and post-peasant populism in Eastern Europe, in: EuropeAsia Studies, 60, 5, 757-771.

Cavazzani, A. (2006): Oltre la modernizzazione. Processi di sviluppo rurale in Europa. Review essay in Agriregioni Europa, December. 
Chloupova, J. (2002): Polish agriculture: Organizational structure and impacts of transition, The Royal Veterinary and Agricultural University, Unit of Economics Working Papers, 3: $1-32-$

Csurgỏ, I./Kovacs, I./Kucerova, E. (2008): Knowledge, power and sustainability in contemporary Europe, in: Sociologia Ruralis, 48, 3, 292-312.

Dow, G. (2003): Governing the firm: Workers control in theory and practice. Cambridge: Cambridge University Press.

Dries, L.T./Reardon, T./Swinnen, J.M. (2004): The rapid rise of supermarkets in central and eastern Europe: Implications for the Agrifood sector and rural development, in: Development Policy Review, 22, 5, 525-556.

Fadaeva, O./Nikulin, A./Vinogradsky, V. (2002): Informal economy of rural households: restructuring of family networks and strategies, in: Neef, R.(ed.), The social impact of informal economies in eastern Europe, Alderhot: Ashgate.

Fonte, M. (2008): Knowledge, food and place: A way of producing, a way of knowing, in: Sociologia Ruralis, 48, 3: 200-222.

Forgacs, C. (2008): Leadership and importance of social capital in cooperative during transition: A case-study of two cooperatives, in: Journal of Rural Cooperation, 35, 2, $57-22$.

Gatzweiler, F. (2003): Patterns of institutional change for sustainability in Central and Eastern European agriculture, in: CEESA Discussion Papers No. 16.

Grancelli, B. (1988): Soviet management and labor relations, Boston: Allen \& Unwin.

Gorton, M./Davidovna S. (2004): Farm productivity and efficiency in the CEE applicant countries: A synthesis of results, in: Agricultural Economics, 30: 1-16.

Granberg, L. (2007): Rural path in Russia, in: Heinonen et al. Reflecting Transformation in Post-Socialist Rural Areas, 49-62.

Gutkowska, K. (2003): Rural households in Poland and the transition process, in: Eastern European Countryside, 9.

Heinonen, M./ Nikula, J./ Kopoteva, I./ Granberg, L. (2007) (eds.): Reflecting transformation in post-socialist rural areas, Newcastle: Cambridge Scholars Publishing.

Juska, A./Poviliunas, A./Pozzuto, R. (2005): Resisting marginalization: The rise of the rural community movement in Lithuania, in: Sociologia Ruralis, 45, 1/2: 3-21.

Kalantaridis, C./Labrianidis, L/Vassilev, I. (2007): Entrepreneurship and institutional change in Post-socialist rural areas: Some evidence from Russia and the Ukraine, in: Journal for East European Management Studies, 12, 1: 9-34.

Kulcsar, L./Domokos, T. (2005): The post-socialist growth machine: The case of Hungary, in: International Journal of Urban and Regional Research, 29, 3: 550-563.

Meurs, M. (2004): The evolution of agrarian institutions. A comparative study of postsocialist Hungary and Bulgaria., Ann Arbor: The University of Michigan Press.

Merret, C.D./Walzer, N. (2004): Cooperatives and local development. Theory and applications for the 21st century. Armonk, N.Y.: Sharpe.

Milczarek-Andrewska, D.A. et al. (2008): Farm-level restructuring in Poland. Evidence from the dairy sector, in: Regoverning Markets (www.regoverningmarkets.org). 
Milgrom, P./Roberts. J. (1992): Economics, organization and management. New Jersey: Prentice Hall.

Mooney, P./Gray, T. (2002): Cooperative conversion and restructuring in theory and practice, in: United States Department of Agriculture, Research Report 185.

Neef, R. (2004): Observations on the concept and forms of the informal economy in Eastern Europe, in: Neef, R.(ed.): The social impact of informal economies in Eastern Europe, Aldershot: Gower.

Oswald, I. (2007): "Industrialized villages" in post-socialist countries - Steps towards an integrative research concept, in: Heinonen et al. (eds.), Reflecting Transformation in Post-Socialist Rural Areas, 215-235.

Ploeg, J.D. van der (2000): Rural development: From practices and policies toward theory, in : Sociologia Ruralis, 40, 4, 391-408.

Porter. P./Scully, G. (1987): Economic efficiency in co-operatives, in: The Journal of Law and Economics, 30, 409-512.

Reardon, T./Swinnen, G.M. (2004): Agrifood liberalization and the rise of supermarket in the former state-controlled economies: A comparative overview, in: Development Policy Review, 22, 5, 515-523.

Sen. A. (1966): Labour allocation in a co-operative enterprise, in: Review of Economic Studies, 33, 331-361.

Sehring, J (2008): Path dependencies and institutional bricolage in Post-Soviet water governance, paper presented at the XII World Congress of Rural Sociology, 6-11 July

Shubin, S. (2007): Networked poverty in rural Russia, in: Europe-Asia studies, 59, 4, 591-620.

Sikor, T. (2002): Institutional Alternatives for sustainable agriculture in Central and Eastern Europe, in: CEESA Project, The Commission of the European Union.

Small, L.A. (2003): The opportunity of subsistence-style agriculture: A livelihood perspective on agrarian change in central and eastern Europe, in: Eastern European Countryside, 9, $1-29$

Sotte, F. (2003): An evolutionary approach to rural development. Some lessons for the policy makers, in: Studi sull'Adriatico e i Balcani, 3, 1-21.

Stark, D. (1996): Recombinant property in Eastern European capitalism, in: American Journal of Sociology, 101, 993-1027

Swain, N. (2000): The Rural transition in post-socialist central Europe and the Balkans, in: Max Planck Institute for Social Anthropology, Working Papers, 9, 1-26.

Swain, N. (1999): Agricultural restitution and cooperative transformation in the Czech Republic, Hungary and Slovakia, in: Europe-Asia Studies, 51, 7, 1199-1219.

Szabợ, G./Kiss, A. (2004): Economic substance and legal regulation of agricultural cooperatives in Hungary, in: Borzaga, C./Spears, R. (2004) (eds.): Trends and challenges for co-operatives and social enterprises in developed and transition countries. Trento: Edizioni 31.

Thesfeld, I./Boevsky, I (2005): Reviving pre-socialist cooperative traditions: The case of water syndicates in Bulgaria, in: Sociologia Ruralis, 45, 3, 171-186. 
Wallace, C./Haerpfer, C. (2004): Patterns of participation in the informal economy in EastCentral Europe, 1991-1998.

Wilkin, J.D. et al. (2006): The dairy sector I Poland, in: Regoverning markets, December.

Windolf, P. (1998), Privatization and elite reproduction in Eastern Europe, Archives Europeennes de Sociologie, 2, 335-374.

Zeuli, K./Deller, S. (2007): Measuring the local economic impact of cooperatives, Journal of Rural Cooperation, 35, 1, 1-18. 